\title{
Increase Serum Tumor Necrosis Factor Alpha decreased Serum Cholesterol Level, but not Albumin, in Hemodialysis Patients with Non-Fibrotic Hepatitis C Infection
}

\author{
Rudi Supriyadi ${ }^{1 *}$ (D), Nenny Agustanti ${ }^{2}$, Marcella Adisuhanto ${ }^{3}$ \\ ${ }^{1}$ Department of Internal Medicine, Division of Nephrology and Hypertension, Faculty of Medicine, Universitas Padjadjaran, \\ Hasan Sadikin General Hospital, Bandung, Indonesia; ${ }^{2}$ Department of Internal Medicine, Division of Gastroenterology and \\ Hepatology, Faculty of Medicine, Universitas Padjadjaran, Hasan Sadikin General Hospital, Bandung, Indonesia; ${ }^{3}$ Department \\ of Internal Medicine, Faculty of Medicine, Universitas Padjadjaran, Hasan Sadikin General Hospital, Bandung, Indonesia
}

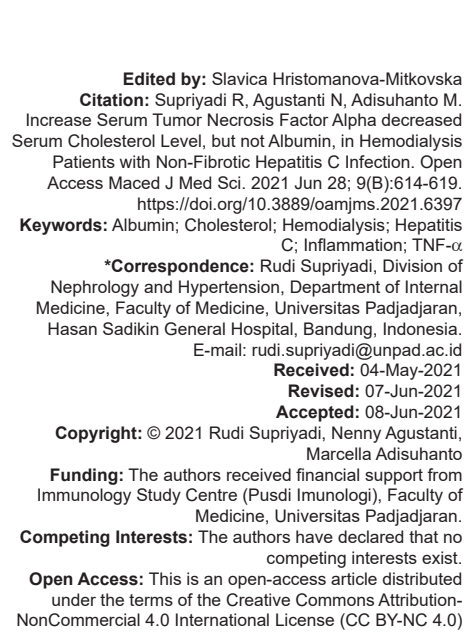

\section{Introduction}

End-stage renal disease (ESRD) is a terminal kidney disorder that causes substantial morbidity and mortality based on inflammation, malnutrition, and atherosclerosis; also known as MIA Syndrome (Malnutrition, inflammation, and atherosclerosis syndrome) [1]. The inflammatory process in patients undergoing chronic dialysis is influenced by various factors, one of which is the comorbid diseases suffered by the patient [2]. One of the most common comorbidities in dialysis patients is hepatitis $\mathrm{C}$ infection, which continues to increase in number [3].

TNF- $\alpha$ is pro-inflammatory cytokines that have been shown to be increased in patients with hepatitis $C$ infection [4]. It could also be increased in dialysis patients [5]. TNF- $\alpha$ is a key regulator of the inflammatory cascade. It also has proatherogenic features by disrupting lipid metabolism [6]. The association of serum TNF- $\alpha$ with nutritional status has been reported previously [7]. However, only a few studies have assessed the correlation between serum TNF- $\alpha$ with serum albumin and cholesterol levels in dialysis patients with hepatitis $C$ infection.

\section{Methods}

This research was an analytical cross-sectional study that was conducted using medical records of patients undergoing chronic hemodialysis in Hasan Sadikin General Hospital, Bandung. This study has been approved by the Health Research Ethics Committee of the Central General Hospital (RSUP) Dr. Hasan Sadikin Bandung with the number LB.02.01/X.6.5/336/2019. The study used medical records of patients undergoing chronic hemodialysis in Hasan Sadikin General 
Hospital. The inclusion criteria were age $\geq 18$ years, while the exclusion criteria were patients with hepatitis B, Human Immunodeficiency Virus (HIV), tuberculosis, autoimmune, malignancy, and liver cirrhosis.

Data collection was conducted in February 2020. The sample selection was carried out using a simple random method and analyzed with the Spearman rank correlation test. Serum TNF-a was measured using the ELISA method (ELISA Kit for TNF$\alpha$, Cloud-Clone Corp, Houston, USA). Serum albumin and cholesterol levels were measured using the spectrophotometry method. Malnutrition-Inflammation Score (MIS), Aspartate aminotransferase to platelet Ratio Index (APRI), and Kt/ $\mathrm{V}$ were calculated to evaluate the nutritional status, hepatic fibrosis, and adequacy of hemodialysis among the samples, respectively.

\section{Results}

One hundred nineteen patients were divided into two groups, with hepatitis $C$ infection $(n=53)$ and without hepatitis $C$ infection $(n=66)$. The median age of the samples was $49(25-77)$ years. The number of men and women was 55 and 64 people. The three most common comorbidities were hypertension (89.2\%), type 2 diabetes mellitus (17.2\%), and chronic heart failure (15.1\%). These results are shown in Table 1.

Serum TNF- $\alpha$ was higher in the hepatitis C infection group than those without hepatitis $C$ infection (31.86 $\mathrm{pg} / \mathrm{ml}$ vs $11.71 \mathrm{pg} / \mathrm{ml} ; \mathrm{p}<0.001$ ). Serum cholesterol in the hepatitis $\mathrm{C}$ infection group was lower than those without hepatitis $C$ infection (139.4 \pm 24.7 vs $165.1 \pm 41.5, p<0.001)$. Serum low-density lipoprotein cholesterol (LDL-C) was also lower in the hepatitis $C$ infection group than those without hepatitis $C$ infection
$(80.4 \pm 23.0$ vs $101.1 \pm 30.4, p<0.001)$. These results are shown in Table 2 . Other laboratory values such as prothrombin time - international normalized ratio (INR), serum high-density lipoproteins cholesterol (HDL-C), and triglycerides did not show any difference between the hepatitis $C$ infection and those without hepatitis $C$ infection. There was no difference in albumin levels between the two groups $(p=0.283)$.

\section{Correlation of serum TNF- $\alpha$ with cholesterol and albumin}

Table 3 shows the correlation of serum TNF- $\alpha$ with serum cholesterol and albumin. There was a negative correlation between serum TNF- $\alpha$ and cholesterol in both hepatitis $C$ infection group $(r=-0.246$; $p=0.039)$ and without hepatitis $C$ infection $(r=-0.256$; $p=0.022$ ). Moreover, there was a correlation between TNF- $\alpha$ levels with LDL-C in both group $(r=-0.279$, $p=0.022$ vs. $r=-0.212, p=0.047)$. After adjusting with the duration of hemodialysis, this association was found to be significant in patients without Hepatitis $C$ infection ( $p=0.02$ ) and borderline significant in patients with Hepatitis $C$ infection $(p=0.09)$. There was no correlation between TNF- $\alpha$ and albumin in both hepatitis $C$ infection group $(r=0.082 ; p=0.281)$ and without hepatitis $C$ infection $(r=-0.168 ; p=0.094)$.

\section{cholesterol}

\section{Correlation of serum albumin and}

From the results of the correlation analysis, there was a positive correlation between serum albumin and cholesterol in the group without hepatitis $C$ infection $(r=0.335, p=0.003)$. There was also a positive correlation between albumin and LDL-C in the same group $(r=0.276, p=0.013)$. In hepatitis $C$ infection group, there was no correlation between

Table 1: Baseline characteristics of dialysis patients with and without hepatitis $C$ infection

\begin{tabular}{|c|c|c|c|c|}
\hline Baseline characteristics & $\begin{array}{l}\text { Total } \\
\mathrm{n}=119\end{array}$ & $\begin{array}{l}\text { Hepatitis C }(+) \\
n=53\end{array}$ & $\begin{array}{l}\text { Hepatitis C (-) } \\
\mathrm{n}=66\end{array}$ & $\mathrm{p}$-value \\
\hline Age (years), median (min-max) & $49(25-77)$ & $49(26-73)$ & $49(25-77)$ & $0.543^{\mathrm{a}}$ \\
\hline \multicolumn{5}{|l|}{ Gender, $\mathrm{n}(\%)$} \\
\hline Man & $55(46.2)$ & $25(47.2)$ & $30(45.5)$ & \multirow[t]{2}{*}{$0.852^{b}$} \\
\hline Woman & $64(53.8)$ & $28(52.8)$ & $36(54.5)$ & \\
\hline \multicolumn{5}{|l|}{ Nutritional status } \\
\hline MIS value, median (min-max) & $4(0-16)$ & $3(0-16)$ & $5(0-11)$ & $<0.001^{a *}$ \\
\hline \multicolumn{5}{|l|}{ Comorbids, $\mathrm{n}(\%)$} \\
\hline Hipertension & $83(89.2)$ & $33(82.5)$ & $50(94.3)$ & $0.093^{\mathrm{c}}$ \\
\hline Diabetes melitus tipe 2 & $16(17.2)$ & $4(10.0)$ & $12(22.6)$ & $0.110^{\mathrm{c}}$ \\
\hline Chronic heart failure & $14(15.1)$ & $10(25.0)$ & $4(7.5)$ & $0.020^{\circ}$ \\
\hline APRI Score, median (min-max) & $0.24(0.05-1.39)$ & $0.35(0.05-1.39)$ & $0.20(0.07-1.24)$ & $<0.001^{a_{*}}$ \\
\hline Duration of Hemodialysis (years), median (min-max) & $5(1-15)$ & $7(2-4)$ & $4(1-15)$ & $<0.001^{\mathrm{a} *}$ \\
\hline Adequacy of Hemodialysis $(\mathrm{Kt} / \mathrm{V})$, median (min-max) & $1.71(0.04-14.86)$ & $1.75(0.44-9.09)$ & $1.71(0.04-14.86)$ & $0.305^{\mathrm{a}}$ \\
\hline
\end{tabular}

$p<0,05$.

Table 2: Laboratory result comparison in the dialysis group with hepatitis $\mathbf{C}$ infection and without hepatitis $\mathbf{C}$ infection

\begin{tabular}{|c|c|c|c|c|}
\hline Basic characteristics & $\begin{array}{l}\text { Total } \\
n=119\end{array}$ & $\begin{array}{l}\text { Hepatitis C (+) } \\
n=53\end{array}$ & $n=66$ & $p$-value \\
\hline Serum Albumin (mg/dl), median (min-max) & $3.39(1.69-4.40)$ & $3.39(2.62-4.40)$ & $3.40(1.69-4.03)$ & 0.283 \\
\hline Serum total cholesterol $(\mathrm{mg} / \mathrm{dL})$, Mean $\pm \mathrm{SD}$ & $153.7 \pm 37.2$ & $139.4 \pm 24.7$ & $165.1 \pm 41.5$ & $<0.001^{a_{*}}$ \\
\hline Serum LDL-C (mg/dL), mean \pm SD & $91.9 \pm 29.2$ & $80.4 \pm 23.0$ & $101.1 \pm 30.4$ & $<0.001^{\mathrm{a} *}$ \\
\hline Serum TNF- $\alpha(\mathrm{pg} / \mathrm{ml})$, median (min-max) & $15.60(0.16-1683.98)$ & $31.86(5.46-1323.68)$ & $11.71(0.16-1683.98)$ & $<0.001^{\mathrm{b*}}$ \\
\hline
\end{tabular}


Table 3: Correlation of serum TNF- $\alpha$ with serum cholesterol and albumin in dialysis patients with and without Hepatitis C infection

\begin{tabular}{|c|c|c|c|c|c|c|}
\hline \multirow[t]{2}{*}{ Variable } & \multicolumn{3}{|c|}{ Albumin } & \multicolumn{2}{|c|}{ Cholesterol } & \multirow[t]{2}{*}{$\mathrm{p}$-value } \\
\hline & $\mathrm{n}$ & R Coefficient & $p$-value & $\mathrm{n}$ & $\mathrm{R}$ coefficient & \\
\hline \multicolumn{7}{|l|}{ Serum TNF- $\alpha$} \\
\hline Total Sample & 119 & -0.078 & 0.205 & 119 & -0.328 & $<0.001^{*}$ \\
\hline $\mathrm{HCV}(+)$ & 53 & 0.082 & 0.281 & 53 & -0.246 & $0.039^{\star}$ \\
\hline $\operatorname{HCV}(-)$ & 66 & -0.168 & 0.094 & 66 & -0.256 & $0.022^{*}$ \\
\hline
\end{tabular}

serum albumin and cholesterol $(r=0.100, p=0.242)$. The data was demonstrated in Table 4.

Table 4: Correlation of serum cholesterol with serum albumin in dialysis patients with and without Hepatitis $\mathbf{C}$ infection

\begin{tabular}{llll}
\hline Variables & \multicolumn{2}{l}{ Serum Albumin $(\mathrm{mg} / \mathrm{dl})$} & $\mathrm{HCV}(-)$ \\
\cline { 2 - 4 } & Total & $\mathrm{HCV}(+)$ & \\
\hline Cholesterol & & & 0.335 \\
R coefficient & 0.249 & 0.100 & $0.003^{*}$ \\
p value & $0.003^{*}$ & 0.242 & \\
LDL-C & & & 0.276 \\
R coefficient & 0.086 & 0.107 & $0.013^{*}$ \\
$\quad$ p value & 0.180 & 0.227 & \\
\hline Analyzed with Spearman's rank correlation LDL-C: Low-density lipoproteins cholesterol
\end{tabular}

\section{Discussion}

Our study showed that the serum TNF- $\alpha$ value was significantly higher in the hepatitis $\mathrm{C}$ infection group than without hepatitis $C$ infection. Increased serum TNF- $\alpha$ signified that there was a chronic inflammatory state in the specific group. Lee et al. mentioned that hepatocytes produce TNF- $\alpha$ in response to HCV infection [8]. Patients undergoing chronic hemodialysis have higher levels of serum TNF- $\alpha$ [5]. Hemodialysisassociated procedures, such as dialyzer membranes and hemodialysis adequacy, could be the cause of this phenomenon [9], [10]. In this study, dialyzer membrane and hemodialysis adequacy were not different in both groups. Therefore, the higher TNF- $\alpha$ in patients with hepatitis $C$ Infection in this study was not influenced by those factors.

\section{Hepatitis C infection and the correlation of TNF- $\alpha$ with cholesterol}

Total serum cholesterol and LDL-C were significantly lower in patients with Hepatitis $C$ infection than patients without Hepatitis C infection (Figure 1). Meanwhile, this study showed a negative correlation between TNF- $\alpha$ and cholesterol in both dialysis groups with and without hepatitis $C$ infection.

Hepatitis C virus (HCV) as a lipid-coated virus makes the liver a place for its life cycle [11]. The intrahepatic life cycle affects lipid metabolism and homeostasis, including synthesizing fatty acids and cholesterol, which are useful in the viral replication process. Disturbance of lipid homeostasis occurs through the transcriptional activation of lipogenic genes that play a role in lipid synthesis and leads to triglyceride accumulation in the liver [12]. Apart from being associated with lipid metabolism in the liver, $\mathrm{HCV}$ can interfere with circulating lipoprotein metabolism and reduce serum cholesterol levels. These findings were supported by Ayman et al., which showed that $\mathrm{HCV}$ eradication was associated with increased total serum cholesterol [13].

Chronic increases in serum TNF- $\alpha$ can inhibit cholesterol production in the liver by inhibiting several enzymes, including ApoA/ApoB and CYP7A1/CYP7B1. This cytokine will reduce the liver's ability to catabolize and excrete cholesterol. Hypocholesterolemia related to inflammation is caused by decreased HDL and LDL production through decreased ApoA-I and apoB by hepatocytes. Furthermore, TNF- $\alpha$ will increase LDL binding on HepG2 cells and increase LDL clearance from the circulation; thus, it will increase the severity of the hypocholesterolemic state. Even though the value seems to be lower, the LDL oxidation process forms a small dense LDL that is smaller, denser, and more atherogenic [6].

Cholesterol synthesis occurs in two ways, exogenous and endogenous pathways. Exogenous source of cholesterol comes from the diet and only occupies a proportion of one-third of the total cholesterol source [14]. The patients' sufficient liver condition indicated that the patients' endogenous source of cholesterol is well-controlled. Thus, the disturbance of cholesterol balance in the subject was only due to the inflammatory process itself. With a sufficient liver condition, overall cholesterol levels remain within normal limits.

The difference in cholesterol levels of patients with hepatitis $C$ infection that tended to be lower than the group without hepatitis $C$ infection in this study indicated an additional cause in the form of hepatitis $C$ infection as a differentiator between these two groups. This was shown by the higher serum TNF- $\alpha$ in the hepatitis $C$ group. The increase in TNF- $\alpha$ levels promotes a higher inflammatory process, affecting cholesterol production even though the liver function was still in good condition.

\section{Correlation of TNF- $\alpha$ with albumin}

Inflammation, as depicted by the increase of serum TNF- $\alpha$, could disturb the nutritional balance and increase the risk of developing atherosclerosis. This process is known as malnutrition, inflammation, and atherosclerosis (MIA) syndrome in ESRD [1]. However, we found no correlation between TNF- $\alpha$ and albumin in the hepatitis $C$ and without hepatitis $C$ infection groups. The results were different with a multivariate analysis study conducted by Yeun et al., which concluded that inflammation and nutritional status were factors that influenced albumin levels in dialysis patients [15].

Many factors contribute to hypoalbuminemia in dialysis patients [15]. TNF- $\alpha$ inhibits albumin production 


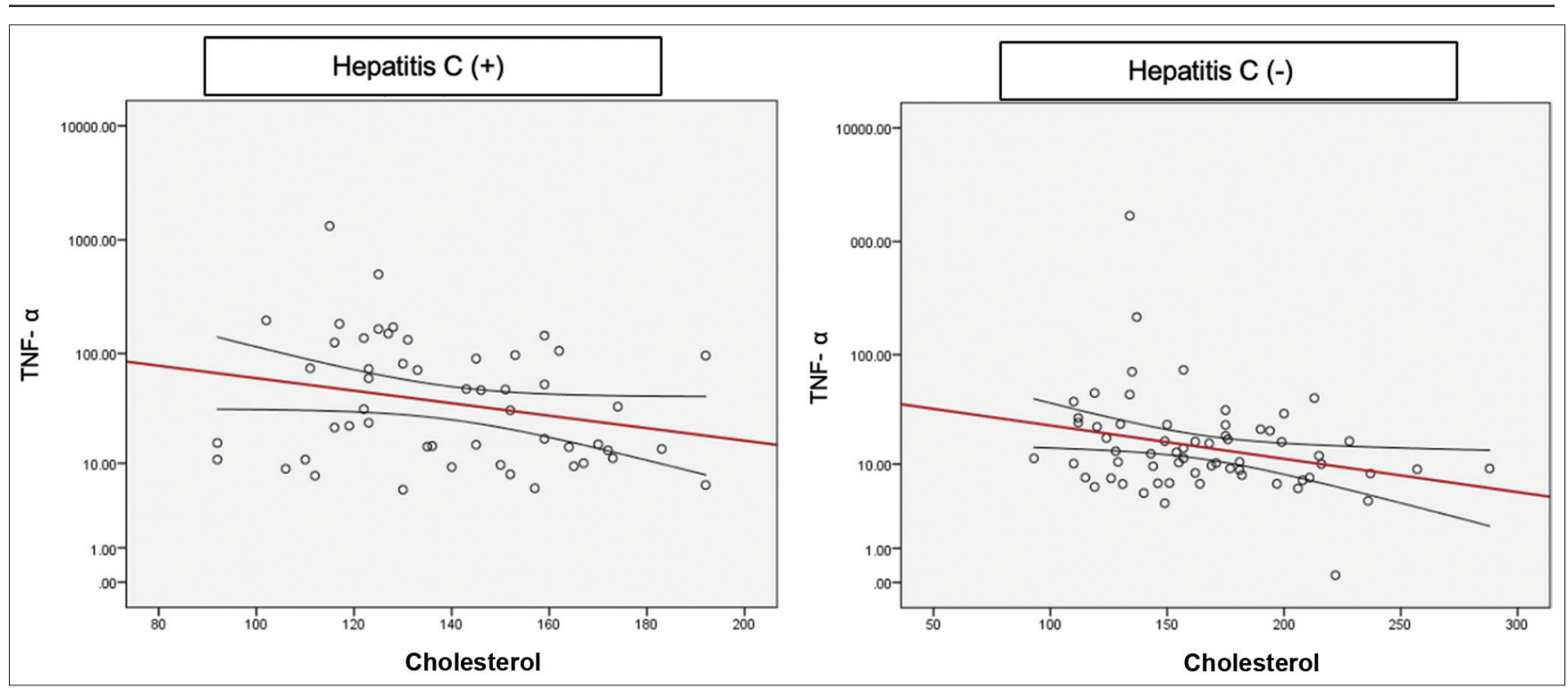

Figure 1: Correlation of serum TNF- $\alpha$ with serum cholesterol in dialysis patients

in the liver, which can cause a decrease in albumin levels [1]. Albumin is the most abundant form of protein in plasma, which acts as an antioxidant to reduce the risk of atherosclerosis, cardiovascular disease, and anti-inflammatory [16].

In addition to its role as inflammatory marker, albumin can also be a marker of nutritional status. Although serum albumin level was reduced in this study, the median serum albumin of the subjects was still deemed 'adequate, with the median value of $3.39 \mathrm{mg} / \mathrm{dl}$. Hypoalbuminemia in dialysis patients without other risks such as a combination of malnutrition and inflammation is rarely lower than $3.0 \mathrm{~g} / \mathrm{dL}$. Without an inflammatory process, it takes a near-starvation state to cause malnutrition, a condition that significantly reduces albumin levels. This happens due to a compensatory process by breaking down proteins from visceral organs and body mass [17]. This further explains that the albumin levels in this research subject are maintained in optimal condition due to adequate nutrition. These findings are also supported by the good nutritional status of this study samples. MIS median value of this sample was $4(0-16)$ and considered as an acceptable "normal" value, whereas MIS> 5 indicates malnutrition [18].

Malnutrition often occurs in dialysis patients, which can be caused by an inflammatory process or often referred to as MIA syndrome. Anorexia and loss of muscle mass are the primary markers of malnutrition. Various cytokines such as TNF- $\alpha$, IL-6, IL-11a, IL-1b, and CRP that increase play a role in reducing the appetite in dialysis patients and inducing anorexia by reducing appetite and increasing energy use. Physiologically, there will be a balance of anabolic and catabolic processes. In dialysis patients, this balance is disturbed. TNF- $\alpha$ cytokines, in particular, will also increase muscle protein catabolism through activation of the ubiquitin-proteasome pathway. Increases in
TNF- $\alpha$ are associated with severe malnutrition in dialysis patients and even correlate with other markers of malnutrition [19].

Moreover, the overall median APRI value of 0.24 was depicting the non-fibrotic nature of the liver. $A$ value less than 0.5 denotes that there is no significant fibrosis [20]. If the liver has been disturbed by more than $50 \%$, the albumin production will also decrease [21]. Therefore, in the absence of fibrosis, it seems that TNF- $\alpha$ also does not play a role in suppressing albumin production in the liver.

\section{Correlation of albumin and cholesterol}

The analysis of this study showed a weak positive correlation between albumin and cholesterol. The decrease in albumin was in line with the decrease in cholesterol levels in the patients without hepatitis $C$ infection. In patients with hepatitis $C$ infection, there was no correlation between albumin and cholesterol. Furthermore, there was a weak positive correlation between albumin and LDL levels in the group without hepatitis $\mathrm{C}$ infection.

The decrease in extracellular albumin concentration led to an increase in the concentration of ApoB-100 and did not affect apoA1 secretion. On the other hand, albumin as an antioxidant and antiinflammatory can also increase LDL catabolism. Apolipoprotein or apoB-100 is a lipoprotein that binds to receptors in LDL and is associated with atherosclerotic plaques [22]. It can be inferred that the correlation between the two is a common condition.

The correlation between serum albumin and cholesterol, which was not proven in the hepatitis $C$ infection group, still needs to be explored. These findings may be due to the significantly lower cholesterol value in the group, while the albumin value 
was relatively the same between the two groups. If there are no other factors that confound one of them, the reduction in cholesterol and albumin levels will be in line. Patients in this study had a good liver function and well-preserved nutrition so that there were no significant problems regarding albumin production or cholesterol. Thus, albumin and cholesterol production in the group without hepatitis $\mathrm{C}$ infection can occur in one direction. In contrast, albumin and cholesterol production was disturbed in the group with hepatitis $\mathrm{C}$ infection, where there was an additional effect on lipids due to the presence of the hepatitis $C$ virus itself.

The major limitation of this study was that it did not include the duration of hepatitis $C$ infection. Duration of hepatitis $\mathrm{C}$ infection might affect the correlation of serum TNF- $\alpha$ with cholesterol and albumin level. Furthermore, another limitation of the study was that the subjects' dietary and nutritional intake details were not evaluated.

\section{Conclusions}

TNF- $\alpha$ level negatively correlates with cholesterol levels in chronic kidney disease patients on hemodialysis with and without hepatitis $C$ infection. However, there was no correlation between TNF- $\alpha$ and albumin level in both groups.

\section{References}

1. Stenvinkel $P$, Heimbürger $O$, Paultre $F$, Diczfalusy $U$, Wang $\mathrm{T}$, Berglund $\mathrm{L}$, et al. Strong association between malnutrition, inflammation, and atherosclerosis in chronic renal failure. Kidney Int. 1999;55(5):1899-911. https://doi. org/10.1046/j.1523-1755.1999.00422.x

PMid:10231453

2. Mihai S, Codrici E, Popescu ID, Enciu AM, Albulescu L, Necula LG, et al. Inflammation-related mechanisms in chronic kidney disease prediction, progression, and outcome. J Immunol Res. 2018;2018:2180373. https://doi. org/10.1155/2018/2180373

PMid:30271792

3. Lydia A, Supriyadi R, Lestari D, Sanitiyoso A, Alvani R, Hasan I. Konsensus Nasional Penatalaksanaan Hepatitis C Pada Penyakit Ginjal Kronik di Indonesia. Jakarta: PPHI dan PERNEFRI; 2019

4. Babiker A, Jeudy J, Kligerman S, Khambaty M, Shah A, Bagchi S. Risk of cardiovascular disease due to chronic hepatitis C infection: A review. J Clin Transl Hepatol. 2017;5(4):343-62. https://doi.org/10.14218/jcth.2017.00021 PMid:29226101

5. Babaei M, Dashti N, Lamei N, Khosrou A, Nazari F, Abbasian S, Gerayeshnejad S. Evaluation of plasma concentrations of homocysteine, IL-6, TNF-alpha, hs-CRP, and total antioxidant capacity in patients with end-stage renal failure. Acta Med Iran.
2014;52(12):893-8.

PMid:25530051

6. Popa C, Netea MG, van Riel PL, van der Meer JW, Stalenhoef AF The role of TNF-alpha in chronic inflammatory conditions, intermediary metabolism, and cardiovascular risk. J Lipid Res. 2007;48(4):751-62. https://doi.org/10.1194/jlr.r600021-j|r200

PMid:17202130

7. Vanitha $N$, Kavimani $S$, Soundararajan $P$, Chamundeeswari $D$. Effect of inflammation on nutritional status of patients on maintenance hemodialysis. Indian J Nephrol. 2016;26(2):154-5. https://doi.org/10.4103/0971-4065.171223

PMid:27051146

8. Lee J, Tian Y, Chan ST, Kim JY, Cho C, Ou JH. TNF- $\alpha$ induced by Hepatitis $C$ virus via TLR7 and TLR8 in hepatocytes supports interferon signaling via an autocrine mechanism. PLoS Pathog. 2015;11(5):e1004937. https://doi.org/10.1371/journal. ppat. 1004937

PMid:26023919

9. Ahmed SI. The relation between the level of serum tumor necrosis factor-alpha and hemodialysis adequacy in diabetic and non diabetic patients on maintenance hemodialysis. Urol Nephrol Open Access J. 2016;3(2):60-5. https://doi. org/10.15406/unoaj.2016.03.00074

10. Bosch-Panadero E, Mas S, Sanchez-Ospina D, Camarero V, Pérez Gómez M, Saez-Calero I, et al. The choice of hemodialysis membrane affects bisphenol A levels in blood. J Am Soc Nephrol. 2015;27(5):1566-74. https://doi.org/10.1681/ asn.2015030312

PMid:26432902

11. González-Aldaco K, Torres-Reyes LA, Ojeda-Granados C José-Ábrego A, Fierro NA, Román S. Immunometabolic effect of cholesterol in hepatitis C infection: Implications in clinical management and antiviral therapy. Ann Hepatol. 2018;17(6):908-19. https://doi.org/10.5604/01.3001.0012.7191 PMid:30600305

12. Felmlee DJ, Hafirassou ML, Lefevre M, Baumert TF, Schuster C. Hepatitis C virus, cholesterol and lipoproteins-impact for the viral life cycle and pathogenesis of liver disease. Viruses. 2013;5(5):1292-324. https://doi.org/10.3390/v5051292 PMid:23698400

13. El-Lehleh A, El-Shiekh M, El-Hamouly M. Study of serum lipid profile before and after Hepatitis C virus treatment. Menoufia Med J. 2019;32(3):1126-31. https://doi.org/10.4103/mmj. mmj_141_19

14. Kapourchali FR, Surendiran G, Goulet A, Moghadasian MH The role of dietary cholesterol in lipoprotein metabolism and related metabolic abnormalities: A mini-review. Crit Rev Food Sci Nutr. 2016;56(14):2408-15. https://doi.org/10.1080/104083 98.2013 .842887

PMid:26055276

15. Yeun JY, Kaysen GA. Factors influencing serum albumin in dialysis patients. Am J Kidney Dis. 1998;32 Suppl 4:S118-25. https://doi.org/10.1016/s0272-6386(98)70174-x PMid:9892378

16. Carvalho JR, Machado MV. New insights about albumin and liver disease. Ann Hepatol. 2018;17(4):547-60. PMid:29893696

17. Kaysen GA. Serum albumin concentration in dialysis patients: Why does it remain resistant to therapy?: Management of comorbidities in kidney disease in the $21^{\text {st }}$ century: Anemia and bone disease. Kidney Int. 2003;64:S92-8. https://doi. org/10.1046/j.1523-1755.64.s87.14.x

18. Rodas LV, Rey LF, Lobazlo JR, Rodriguez FL, Goitia BT, Osinaga JA. Malnutrition inflammation score: Screening tool to predict desnutrition in patients under hemodialysis. Clin Nutr. 
2018;37:S207-8. https://doi.org/10.1016/j.clnu.2018.06.1745

19. Sharma R, Agrawal S, Saxena A, Sharma RK. Association of IL-6, IL-10, and TNF- $\alpha$ gene polymorphism with malnutrition inflammation syndrome and survival among end stage renal disease patients. J Interferon Cytokine Res. 2013;33(7):384-91. https://doi.org/10.1089/jir.2012.0109

PMid:23777202

20. Hasan IG, Sulaiman AS, Lesmana CR, Kurniawan J, Jasirwan CO, Kalista KF, et al. Konsensus Nasional Penatalaksanaan Hepatitis C di Indonesia. Jakarta: Perhimpunan Peneliti Hati Indonesia; 2017. p. 14.
21. Nallagangula KS, Nagaraj SK, Venkataswamy L, Chandrappa M. Liver fibrosis: A compilation on the biomarkers status and their significance during disease progression. Future Sci OA. 2017;4(1):FSO250. https://doi.org/10.4155/fsoa-2017-0083

\section{PMid:29255622}

22. Cianflone $\mathrm{K}, \mathrm{Vu} \mathrm{H}$, Zhang Z, Sniderman AD. Effects of albumin on lipid synthesis, apo B-100 secretion, and LDL catabolism in HepG2 cells. Atherosclerosis. 1994;107(2):125-35. https://doi. org/10.1016/0021-9150(94)90014-0

PMid:7980689 